\title{
The Influence Quantum Learning Model To Critical Thinking Ability
}

\author{
Yulistina Nur DS a,1, Tia Latifatu Sadiah ${ }^{\text {a,2 }}$, Sinta Maria Dewi ${ }^{\text {a,3 }}$ \\ ${ }^{a}$ PGSD, Universitas Buana Perjuangan, Indonesia, West Java, Karawang \\ 1yulistina.nur@ubpkarawang.ac.id*; ${ }^{2}$ tia.latifatu@ubpkarawang.ac.id, \\ ${ }^{3}$ sintamaria@ubpkarawang.ac.id*
}

\begin{abstract}
The problem in this study was the low skill of students' critical thinking, especially in the subjects of natural science. This is due to the limited learning model used by a teacher in schools. Preliminary observations by researchers have shown that teachers still use conventional learning models. This research is to know the difference of critical thinking ability of students who implement quantum learning model with the critical thinking ability of students who do not apply the quantum learning of fifth-grade students in natural science subjects at Warungbambu III Elementary School East Karawang. The research methods in this research using a quasiexperimental design with a nonequivalent control group design. The data analysis technique to test hypotheses is done by calculating the statistical independent t-test Samples. Based on the results shows that there are differences in students' critical thinking skills implementing the quantum learning model with the critical thinking skill of students who do not apply the quantum learning model of fifth-grade students in natural science subjects at Warungbambu III Elementary School East Karawang. It is evidenced by the value of sig (2-tailed) $0,000 \leq 0.05$, which means that the hypothesis is accepted.
\end{abstract}

Keywords:

Quantum Learning Model, Critical Thinking Ability

This is an open access article under the CC-BY-NC license.

\section{INTRODUCTION}

One of the problems facing the world of education today is the weakness in the implementation of the learning process applied by the teachers in the school. The learning process has been less capable of developing learners' thinking ability. The implementation of the learning process that takes place in the classroom is only geared toward the ability of learners to memorize information, the brains of learners are forced only to remind and cause a variety of information without being required to understand the information obtained to relate it to the situation and daily life.

In the educational world, the objectives are not separated from the teacher's role. Teachers who work professionally make a great contribution to achieving goals in learning. The professionalism of teachers under the law of the Republic of Indonesia No.14 of 2005 article 20 of teachers and lecturers is to plan to learn, execute quality learning processes, and assess and evaluate learning outcomes. The good teacher's performance is drawing on their performances from both the 
academic to be teachers, meaning it is able to manage teaching in the classroom and educate students outside the classroom with the best.

The management of teachers in the teaching can be seen from packing into something fun according to the characteristics of the students. In elementary school students, their characteristics tend to still think concrete.

Based on a discussion on learning that is expected to optimize students' activities and critical thinking skills, it is in learning the importance of actively engaging students in the process of attribution to some ideas and the construction of science through its environment.

This condition in accordance with the teacher's observation on 27 October 2018 in SD Negeri Warungbambu III related to the natural science learning process in class $\mathrm{V}$ there are several things found, among others: a) learning activities in the classroom that tend to use conventional learning models such as lectures.; b) Questioning and assignment so that interaction in teaching and learning activities tends to be one-way, from teacher to student.

The researcher also does observations at the school, about critical thinking ability in natural science on the subject hydrological cycle. The researcher gave 20 minutes for students to answer five essay questions. The result of the observation showed that most students still do not understand the concept.

The response above the problems is "the teachers need to consider the use of learning model in the learning process so the learning more effective, attractive, and efficient." One model of learning that can overcome this challenge is the quantum learning model. The learning model is expected able to provide a solution for a teacher in teaching natural science and improve learners' critical thinking skills. Based on the Syaefudin's opinion (in Rumapea, 2017:119) "quantum learning is one of the models, strategies, and learning approaches particularly concerning teachers' skill in designing, developing, and managing learning systems so that teachers are able to create an effective learning environment, exciting, and have life skills. Thus the quantum learning model is a form of innovation changing assortment of interaction that exists in and around the moment of learning. These interactions include elements of effective learning that affect student success in learning. From the interaction of changing students' natural abilities and talents into the light which would be beneficial for themselves and for others".

Based on the clarification above, the researcher is interested in conducting research about "The Influence Quantum Learning Model To Critical Thinking Ability."

\section{Research Purpose}

This study aims to know the difference of critical thinking ability of students who implement quantum learning model with the critical thinking ability of students who do not apply the quantum learning of fifth-grade students in natural science 
subjects at Warungbambu III Elementary School East Karawang in academic Year 2018/2019.

Benefits of the research:

This research was conducted with the hope benefits include:

1. As input for SDN Warungbambu III, especially the natural science teacher in elementary school about the importance of the quantum learning model in learning natural science subjects.

2. As a guide for a researcher in performing the task as a natural science teacher in elementary school, to improve critical thinking ability.

\section{LITERATURE REVIEW}

Majid (2014:199) says, "that the critical thinking ability is thought to be based on something logical. Fisher (2008:3) argues that critical thinking is a skilled activity, which can be done better or vice versa, and good critical thinking will meet a variety of intellectual standards, such as clarity, relevance, adequacy, coherence, and others". Dewey (in Fisher, 2008:3) defines critical thinking skill is a) An attitude to think deeply about the problems and things that differ in the reach of someone's experience; b) Knowledge of logical models of examination and reasoning; c) Sort of skill to implement these models.

Ennis (1996:364) argues there are six basic elements in critical thinking ability that are shortened to the FRISCO is: "1) Focus; 2) Reason; 3)
Inference; 4) Situation; 5) Clarity; 6) Overview". Amir (2015:162) argues that critical thinking skill is a person's mental activity in collecting, categorizing, analyzing, and evaluating information or evidence in order to make a conclusion to solve a problem. Ennis (in Fisher, 2008:3) defines critical thinking skill as a sensible and reflective thought and focus on deciding what to believe or see.

Based on the clarification above, it is concluded critical thinking skill is students' thinking skill in analyzing information using evidence and logic in the thought process. The critical thinking skill is also the ability to provide explanations, organize, and use the right strategy in resolving problems, as well as the ability to draw conclusions from a problem.

Seifers and Hoffnung (in Desmita, 2010:154) states the critical thinking ability components there are four, as follows :
a. Basic operations of reasoning.
b. Domain-specific knowledge.
c. Metacognitive knowledge.
d. Values, beliefs, and dispositions.

From the above explanation can be concluded that critical thinking characteristics can be applied to children to make them active in teaching-learning, especially in natural science learning.

States Amir (2015:162), an indicator of critical thinking ability is one's mental activity in 1) collecting, 2) Categorize, 3) Analyze, 4) Evaluate, 5) Conclude. With the presence of an indicator in the ability of critical thinking, every child is expected to be active and creative to solve an existing problem with existing learning. 
Its essential learning is very related to how to build good interactions between two components, teacher dan student. Good interactions can be described in a condition where teachers can learn easily and be encouraged by their own ability to learn what is in the curriculum as they need. Trianto $(2009,17)$ defines "learning is a conscious effort from a teacher to teach its students (directing the interaction of students with other learning resources) in order to achieve the expected objectives, and from this meaning, it is clear that learning is a bidirectional interaction from a teacher and a student, where between the two occurs intense and direction communication (transfer) that is pointed at the predetermined target."

Iskandar (2001:2) declare natural science is a science that learns the events that occur in nature. The natural science discusses the systematic symptoms of nature based on the results of the experiments and human observations. It is powered by Winaputra (In Samatowa, 2011:3) say that is not only a collection of knowledge about objects or living beings, but it requires work, way of thinking, and how to solve problems.

DePorter and Hemacki (2001:12) say that quantum learning has to benefit: a) Be positive, b) Increase motivation, c) Lifelong learning skill, d) Confident, e) Be Success. Eggen and Kauchak (in Sunaryo, 2001:1) say that student learns effectively when students are actively involved in organizing the discovery of the association of information data encountered. Students are said to be active when participating in preparing lessons, joyful in learning, having the will, and creativity in learning. Bravery conveys ideas and interests, critical and curious attitudes, seriousness work in accordance with inductive reasoning development procedures, and development of deductive reasoning.

Quantum learning has a principle that the main principle brings their world and our work take to their world. Those principles are (Guman Rumapea, 2017:121-122) :

\section{Everything speaks}

The point is the whole of the classroom environment, teacher's body language, learning design should be designed able to carry the message of learning that can be accepted by the students.

\section{Everything has a purpose}

Each activity of learning undertaken by teachers without expectation must have a clear purpose and control.

\section{Experience before naming}

Our brain is developing rapidly in the presence of complex stimuli, which will stir curiosity. Therefore, before the students learn to give names (define, conceptualize, distinguish, categorize) should have had the experience of information related to effort to provide the name.

\section{Acknowledge every effort}

Every student's effort in learning must be given recognition by teachers and other students. This 
recognition is important, so the students always bold to step into the next section in learning.

\section{If it is worth learned then it also the worth celebrated}

Every effort and result obtained by students in the learning worth celebrating. Celebrations provide motivation feedback on progress and improve the next learning outcomes.

Guman Rumapea (2017:122) declares: "Quantum learning has a framework knows as TANDUR (Grow, Experience, Naming, Demonstrate, Repeat, and (elebrate). a). "Grow: the student's learning interest with provides students a view that the subject matter delivered will benefit the lives of the students." b). "Experience: Create or bring common experiences that can be understood by all students." c). "Naming: In presenting the material of learning, the teacher provides keyword, concept models, formulas, or input." d)."Demonstrate: Students must demonstrate the material of learning being taught so that students can master the material well".e) "Repeat: Repetition will strengthen nerve connections and sharpen students' memory." f) "Celebrate: Every effort is made by students deserve given recognition. So that students more confident and more enthusiastic about participating in the next material".

\section{METHODOLOGY}

This research used quantitative approaches with experimental methods. Sugiyono (2017:107) defines "reveals that the experimental method is a method that is a part of the quantitative method that has its own characteristic, namely the control group." The design patterns of this research are as follows:

\section{Table 3.1 Research Design}

\begin{tabular}{|l|c|c|c|}
\hline Group & PreTest & Models & Posttest \\
\hline 1 "(Experiment)" & $\mathrm{O}_{1}$ & $\begin{array}{c}\text { Use Quantum } \\
\text { learning } \\
\text { Model }\end{array}$ & $\mathrm{O}_{2}$ \\
\hline 2 "(Control)" & 03 & - & $0_{4}$ \\
\hline
\end{tabular}

$0_{1}$ : "Pretest experiment class"

$\mathrm{O}_{2}$ : "Posttest experiment class"

$\mathrm{O}_{3}$ : "Pretest control class"

$\mathrm{O}_{4}$ : "Posttest control class"

$X:$ "Treatment of experimental groups using quantum learning models."

The stages of the study are: "1) conduct a survey and apply to the school; 2) instrument making, instrument validation, and instrument testing; 3) conducting research surveys; 4) held coordinator with the teacher; 5) carried out the preliminary test (pretest); 6) conducting learning with the quantum learning model and who do not use the quantum learning model; 7) conducting the final test (posttest) of the experimental group and control group".

The population is all students in class $\mathrm{V}$ Warungbambu III District Karawang Timur, which amounted to 40 students divided into two classes $\mathrm{A}$, class A of 20 students, class B that amounted to 20 students. 
Table 3.2 Sample Research

\begin{tabular}{|c|c|c|c|}
\hline Group & Class & Amount & Learning \\
\hline Control & VA & 20 & Conventional Models \\
\hline Experiment & VB & 20 & $\begin{array}{c}\text { Quantum Learning } \\
\text { model }\end{array}$ \\
\hline
\end{tabular}

The techniques data collection used in this study is testing. In this study, tests were a student to measure students' critical thinking abilities that were developed and adapted to the characteristics of the development of elementary school students by giving a question as many as 15 items, which are used in pretest and post-test.

\section{METHODOLOGY}

\section{Descriptive statistics}

Descriptive statistics "are statistics that are used to analyze data by describing or describing data that has been collected as it does without a conclusion that applies to the public or generalization." The size of a descriptive statistic can go through calculation mode, median, and mean (average). The data used is data obtained through pretest and posttest in both groups of experiments against the critical thinking ability of elementary school students.

\section{Inferential statistics}

\section{a. Test normality}

This normality test is performed to determine if the sample is derived from a normally distributed population. Calculation of the normality test with the help of SPSS version 22 in this study, test normality performed using the Kolmogorov-Smirnov Test. The hypothesis is used as follows:

Ho: "Data with normal distribution, if the value of Sig $<0,05$ then Ha received"

Ha: "Data is not distribution normally if the value of Sig $>0,05$ then Ho accepted"

b. Test homogeneity

A homogeneity test is done to know the similarities between two states or populations. A homogeneity test is done by looking at the population homogenization state. Calculation of "homogeneity test with the help of SPSS version 2".

The hypothesis used is:

Ho: "Classes that use quantum learning models and classes that do not use the quantum learning model have the same variances."

Ha: "Classes that use quantum learning models and classes that do not use the quantum learning model do not have the same variances."

The criteria for decision making are as follows:

1. Significance $<0,05$ then the data is not homogeneous

2. Significance $\geq 0,05$ then the data is homogenous.

c. Statistical hypothesis

The hypothesis test is done to test whether the hypothesis corresponds to research. Result of the data obtained to determine the presence or absence of influence. As for testing the hypothesis, use the following formula:

$H_{0}=\mu_{1}=\mu_{2}$ 
$H_{a}=\mu_{1} \neq \mu_{2}$

Ho: if there is no difference between the classes that use the quantum learning model and who do not use the quantum learning model

$\mathrm{Ha}$ : if there is a difference between classes that use quantum learning models and who do not use quantum learning models.

\section{RESULT AND DISCUSSION}

The initial ability of critical thinking is derived from the pretest result performed at the first meeting. Descriptive and pretest critical thinking ability using the help of SPSS program version 22 is shown on the following table.

Table 4.1 Pretest Value Critical Thinking Descriptive Statistics

\begin{tabular}{|l|l|l|l|l|l|}
\hline & $N$ & Min. & Max. & Mean & Std. Deviation \\
\hline Pre-Test & 20 & 40 & 80 & 56,00 & 10,661 \\
Experimental & & & & & \\
Post-Test & 20 & 68 & 96 & 81,47 & 7,464 \\
Experimental & & & & \\
Pre-Test & 20 & 40 & 72 & 57,07 & 8,909 \\
Control & & & & & \\
Post-Test & 20 & 60 & 92 & 75,47 & 8,253 \\
Control & & & & & \\
\hline
\end{tabular}

Based on the table above, it appears that the average pretest grade value of the experiment is 56,00 and 57,07 the average value for the control class. This indicates that the average value of the experiment class is smaller than the control class. The maximum value for the experiment group is 80 , and the control group only reaches 72 . However, the experiment and control group minimum values are equal to 40. In addition, the standard deviation of the 10,661 experiment group is higher than the control group 8,909.

After providing learning in the experiment class using the quantum learning models, it is known that based on the statistical results in the 4.1 table can be seen for experimental classes of average posttest values of 81,47 while the control group of 75,47 of posttest result data is obtained the average value of both classes is very different where the value of the experiment class is higher. In addition, the maximum value and minimum value in both groups is increased compared to the pretest, the maximum value for the experiment group is 96 higher than the control group of only 92, while the group's minimum value an experiment of 68 while the control group amounted to 60 .

Before the hypothesis testing was conducted using test-t, the prerequisite testing used for data analysis in the form of normality test and homogeneity test. The test result of normality can be presented in the following table: 
Table 4.2 Test of Normality

\begin{tabular}{|c|c|c|c|c|}
\hline \multirow{2}{*}{} & Class & \multicolumn{3}{|c|}{ Kolmogorov-Smirnova } \\
\cline { 3 - 5 } & & Statistic & Df & Sig. \\
\hline $\begin{array}{c}\text { Critical } \\
\text { Thinking } \\
\text { Ability }\end{array}$ & $\begin{array}{c}\text { Exsperiment } \\
\text { class }\end{array}$ &, 146 & 20 &, 101 \\
\cline { 2 - 5 } & Control class &, 146 & 20 &, 105 \\
\hline
\end{tabular}

Based on the test result the normality of data above indicates that the data is normal distribution (Sig. 0,101>0,05\& Sig. 0,105>0,05).

The test result of homogeneity can be presented in the following table:

\section{Table 4.3 Test of Homogeneity of Variances}

\begin{tabular}{|c|c|c|c|}
\hline $\begin{array}{c}\text { Levene } \\
\text { Statistic }\end{array}$ & $\mathrm{df1}$ & $\mathrm{df2}$ & Sig. \\
\hline, 569 & 1 & 38 &, 454 \\
\hline
\end{tabular}

The table of calculation results of the homogeneity test above indicates that the significance level of data is 0,454 because of 0,454 $>0,05$. This proves that both samples from the experimental class and the control class come from a homogeneous class.

Hypothesis testing is conducted to determine if there is a difference in the average critical thinking ability of the experimental group students and the control group in natural science learning.
Table 4.4 Hypothesis Test Result Independent

\section{Samples Test}

\begin{tabular}{|c|c|c|c|c|}
\hline & \multicolumn{2}{|c|}{$\begin{array}{c}\text { Critical thinking } \\
\text { Ability }\end{array}$} \\
\hline & & & $\begin{array}{c}\text { Equal } \\
\text { variance } \\
\mathrm{s} \\
\text { assumed }\end{array}$ & $\begin{array}{c}\text { Equal } \\
\text { variance } \\
\text { s not } \\
\text { assumed }\end{array}$ \\
\hline \multirow{2}{*}{$\begin{array}{l}\text { Levene's } \\
\text { Test for } \\
\text { Equality o } \\
\text { Variances }\end{array}$} & \multicolumn{2}{|l|}{$\mathrm{F}$} & , 101 & \\
\hline & \multicolumn{2}{|l|}{ Sig. } & ,752 & \\
\hline \multirow{7}{*}{$\begin{array}{l}\text { t-test for } \\
\text { Equality of } \\
\text { Means }\end{array}$} & \multicolumn{2}{|l|}{$t$} & 3,207 & 3,207 \\
\hline & \multicolumn{2}{|l|}{ df } & 38 & 57,467 \\
\hline & \multicolumn{2}{|c|}{ Sig. (2tailed) } & ,000 & ,000 \\
\hline & \multicolumn{2}{|c|}{ Mean Difference } & , 15033 & 15033 \\
\hline & \multicolumn{2}{|c|}{ Std. Error Difference } & ,04688 & ,04688 \\
\hline & \multirow{2}{*}{$\begin{array}{c}95 \% \\
\text { Confidence } \\
\text { Interval of } \\
\text { the } \\
\text { Difference }\end{array}$} & Lower & 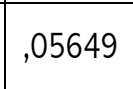 & ,05647 \\
\hline & & Upper & 24417 & ,24419 \\
\hline
\end{tabular}

Based on the test table $-\mathrm{t}$ can know that the T-count value of 3,207 is greater than the T-table 2,021 and its significance $(0,000<0,05)$. This means that $\mathrm{Ho}$ is rejected and $\mathrm{Ha}$ is acceptable meaning there is an average difference between the experiment class or the control class. The positive tcount value indicates that the average class of the experiment group is higher than the average control class.

\section{CONCLUSION}

Based on the results of the study can be concluded that learning using the quantum learning model can affect the students' critical thinking ability in the V class of SDN Warungbambu III on the subjects of natural science. The result was shown 
through the results of a hypothesis test analysis conducted with the T-test using the program SPSS Version 22 with a significant level 0,05 obtained the result of the value sig $=0,000<0,05$. From the process of calculation obtained, "T-calculate value of 3,207 , T-table value 2,021 . From the comparison of T-count is greater than T-table ( $\mathrm{T}$-count $=3,207>$ T-table=2,021)" . Thus Ha accepted, and Ho rejected, it can be concluded that there is a difference in the critical thinking ability of the natural science concept using quantum learning model with the critical thinking ability of the concepts natural science that does not use quantum learning model.

\section{REFERENCES}

DePorter. B, Reardon. M, Nourie. (2005). Quantum Teaching. Bandung: Kaifa.

Desmita. (2009). Psikologi Perkembangan Peserta Didik. Bandung : PT Remaja Rosdakarya.

Dimyanti and Mudjiono. (2009). Belajar dan Pembelajaran. Jakarta: Rineka Cipta.

Ennis, R.H. (1985). Goals for a Critical Thinking Curriculum. In A.L. Costa (Ed.). Developing Minds: A Resource Book for Teaching Thinking. Virginia: Assosiation for Supervisions and Curriculum Development (ASCD).

Fisher, Alec.(2008). Berpikir Kritis Sebuah Pengantar. Jakarta: Erlangga.

Goman Rumapea, Edi Syahputra, Edy Surya. (2017). Application of Quantum Teaching Learning Model to Improve Student Learning Outcomes. International Journal of Novel Research in
Education and Learning Vol.4 Issue 2, pp: (118130): State University of Medan Indonesia.

Majid, Abdul. (2014). Strategi Pembelajaran. Bandung: PT Remaja Rosdakarya.

Mohammad, Faizal, dkk. (2015). Proses Berpikir Kritis Siswa Sekolah Dasar Dalam Memecahkan Masalah Berbentuk Soal Cerita Matematika Berdasarkan Gaya Belajar. Jurnal Math Educator Nusantara Vol. 01 No.02. Universitas Muhammadiyah Sidoarjo.

Rahmawati, Farida. (2011). Skripsi: Menigkatkan Keterampilan Berpikir Kritis Tentang Sifat-Sifat Bangun Ruang dengan Menerapkan Tipe Numbered Together Pada Siswa Kelas V SD Negeri Balerejo 01 Kebon sari Madiun Tahun Pelajaran 2010/2011. Surakarta: Universitas Sebelas Maret.

Samatowa, Usman. (2011). Pembelajaran IPA di SD. Jakarta:Indeks.

Sugiyono. (2017). Metode Penelitian Kuantitatif, Kualitatif dan R\&D. Bandung:Alfabeta. 